\title{
FAKTOR DETERMINAN PERILAKU SEKS PRANIKAH PADA SISWA SMK DI KOTA MAKASSAR TAHUN 2017
}

\author{
Mar'atussaliha ${ }^{1,}$ suharni $^{2}$, Khidri Alwi ${ }^{3}$ \\ ${ }^{1}$ Pasca sarjana universitas muslim Indonesia Makassar \\ ${ }^{2}$ Pasca sarjana universitas muslim Indonesia Makassar \\ ${ }^{3}$ Pasca sarjana universitas muslim Indonesia Makassar
}

Alamat korespondensi : (maratussaliha88@yahoo.co.id /081241246888)

\begin{abstract}
ABSTRAK
Masa remaja dimulai sejak seseorang menunjukkan tanda-tanda pubertas dan berlanjut hingga kematangan seksual tetapi emosi dan kepribadian remaja masih labil sehingga rentan terhadap berbagai godaan dalam lingkungan pergaulan termasuk perilaku seksual remaja. Penelitian ini bertujuan untuk Menganalisis perilaku siswa secara mendalam terkait dengan faktor penyebab terjadinya seksual pranikah yang berhubungan dengan pengetahuan siswa, peran sekolah yang memberi materi mengenai seks bebas, paparan media, perilaku pacaran yang menyebabkan seksual pranikah, dan pengaruh teman sebaya. Jenis penelitian yang digunakan dalam penelitian ini menggunakan metode kualitatif dengan pendekatan fenomelogi dengan teknik pengumpulan data melalui indepth-interview sebanyak 9 informan dan melakukan observasi serta dokumentasi secara terus menerus selama penelitian berlangsung. Hasil penelitian ini menunjukkan bahwa pengetahuan siswa mengenai seksual pranikah hanya sebatas tahu saja walaupun dalam pihak sekolah telah memberikan seminar tentang kesehatan reproduksi pada Seks Pranikah. Perilaku dengan berduaan dan mengekspresikan perasaannya dalam bentuk sentuhan adalah suatu hal yang wajar dan hal tersebut dikuatkan oleh kondisi lingkungan dari teman sebaya yang sudah terbiasa melihat siswa lain berpacaran di depan umum tanpa disertai rasa malu. Selain itu hal yang memicu perilaku seks pranikah adalah peran media yang semakin mudah untuk mengakses gambar atau video porno sehingga siswa merasa lebih mudah mengeksplorasi perasaan pada masing-masing pasangan dalam hal saling mencintai.
\end{abstract}

Kata kunci: Siswa, Pengetahuan, Perilaku, Seksual Pranikah.

\section{PENDAHULUAN}

Remaja pada masa perkembangannya dihadapkan pada tuntutan yang sering bertentangan, baik dari orang tua, guru, teman sebaya, maupun masyarakat di sekitar. Sehingga mereka juga sering dihadapkan pada berbagai kesempatan dan pilihan, yang semuanya itu dapat menimbulkan permasalahan bagi mereka. Permasalahan tersebut salah satunya yaitu resiko-resiko kesehatan reproduksi. Resiko-resiko itu adalah berperilaku seksual, seks bebas, kehamilan yang tidak diinginkan (KTD), aborsi, penyakit menular seksual (PMS), HIV/AIDS, kekerasan seksual, serta masalah keterbatasan akses terhadap informasi dan pelayanan kesehatan (Rizki, 2012).

kelompok remaja berjumlah 1,2 milyar atau $18 \%$ dari jumlah penduduk dunia (WHO, 2014).

Menurut Data WHO (2012) ditemukan sekitar 16 juta anak perempuan berusia 15 sampai 19 tahun dan 2 juta anak perempuan di bawah usia 15 tahun melahirkan setiap tahun. Di seluruh dunia, satu dari lima anak perempuan telah melahirkan pada usia 18 tahun. Di negara-negara berpenghasilan rendah dan menengah, lebih dari $30 \%$ anak perempuan menikah sebelum berusia 18 tahun, dan sekitar $14 \%$ menikah sebelum usia 15 tahun (WHO, 2012).

Data BKKBN 2015 menunjukkan bahwa sebesar $48-51 \%$ perempuan yang hamil merupakan usia remaja. Data BKKBN juga menyebutkan bahwa terjadi 2.500 .000 kasus aborsi di Indonesia setiap tahunnya dengan berbagai alasan. Sebanyak 800.000 kasus dilakukan pada usia remaja 15-19 tahun sehingga diperkirakan setiap hari ada 2.000 remaja yang melakukan aborsi (BKKBN 2015).

Kehamilan pada usia kurang dari 15 tahun yaitu $0,03 \%$ dan $2,71 \%$ pada umur $15-$ 19 tahun terutama terjadi di pedesaan. Hal ini biasanya disebabkan oleh faktor rendahnya pengetahuan tentang kesehatan reproduksi yang berujung pada kehamilan diluar pernikahan atau kehamilan yang tidak diinginkan (Kementerian Kesehatan RI,2013).

Dari data Dinkes 2012 Kota Makassar termasuk daerah yang beresiko tinggi karena 
selain merupakan daerah tujuan wisata, faktor lifestyle masyarakat perkotaan telah bergeser, yang sangat dimungkinkan oleh pengaruh globalisasi dimana budaya luar tersebar dengan cepat seperti Free Sex, penyalah gunaan Napza, kelompok resti seperti waria, yang masih terselubung dalam masyarakat. Selain itu perilaku seks menyimpang juga merupakan salah satu sumber penularan penyakit menular seksual termasuk HIV/AIDS. Pada tahun 2012 kasus HIV/AIDS menurun yang diakibatkan perilaku seks bebas yaitu 493 kasus yang ditemukan di Puskesmas dan Rumah Sakit (Dinkes, 2012).

Fenomena perilaku seksual peranikah di kota Makassar sudah semakin memprihatinkan dimana tempat hiburan seperti tempat karaoke sudah sangat menjamur dimana-mana, kafe, penginapan, dan tempat wisata yang menjadi tempat berkumpulnya remaja atau menjadikannya tempat berduaan untuk berpacaran.

Berdasarkan survey pendahuluan oleh peneliti di SMK Kota Makassar, diperoleh informasi bahwa pengetahuan siswa/siswi mengenai pacaran merupakan hal yang biasa terlihat karena mereka tidak lagi merasa malu untuk pacaran ditempat umum, hal ini dipengaruhi oleh pengetahuan yang kurang terhadap dampak yang akan terjadi, terutama remaja putri akan dapat menyebabkan kehamilan pada usia belasan tahun dan akan mengakibatkan risiko-risiko tertentu baik bagi ibu atau janin yang dikandungnya. Dari jumlah 32 siswa di kelas XI didapatkan hasil 3 diantaranya pernah berpacaran, berkencan dan bercumbu pada saat pulang sekolah. dan kelas XII yang berjumlah 29 siswa didapatkan hasil 2 diantaranya pernah berpacaran sampai melakukan hubungan seks pranikah di rumah pada saat tidak terdapat orang di rumahnya, didapatkan pula informasi pada tahun 2014 ada beberapa siswa/siswi sering melakukan pelanggaran sekolah seperti menonton film/video pornografi pada jam pelajaran, sehingga siswa/siswi yang lain merasa terganggu, berduaan di lingkungan sekolah hingga akhirnya siswi tersebut minggat dari rumahnya. Sedangkan pada tahun 2016 terjadi kasus kehamilan yang tidak diinginkan sehingga siswi tersebut harus putus sekolah dan menikah di usia dini.

Berdasarkan uraian diatas maka peneliti tertarik untuk menggali secara mendalam tentang Faktor Determinan Perilaku Seks Pranikah Pada Siswa SMK Di Kota Makassar.

\section{BAHAN DAN METODE}

Lokasi, Populasi, Sampel

Penelitian ini akan dilaksanakan di SMK
Kota Makassar. Pengumpulan data mulai bulan Agustus sampai September 2017.

Penelitian ini menggunakan metode Kualitatif Deskriptif dengan pendekatan fenomelogi, yang bermaksud untuk mengeksplorasi Faktor Determinan Perilaku Seks Pranikah Pada Siswa SMK Di Kota Makassar. Dengan menggunakan teknik Indept Interview (wawancara mendalam), dan melakukan Observasi serta Dokumentasi secara terus menerus selama penelitian berlangsung.

Teknik penentuan informan dengan menggunakan purposive sampling. Dalam penelitian ini peneliti membagi tiga jenis informan yaitu :

Informan penelitian

1. Informan Biasa atau utama adalah remaja siswa/siswi di SMK Kota Makassar yang memiliki pacar dan pernah pacaran sampai melakukan seks bebas yang bersedia untuk terlibat dalam penelitian.

2. Informan pendukung adalah guru BK di SMK Kota Makassar.

3. Informan Kunci adalah psikologi dan bersedia untuk terlibat dalam penelitian.

Pengumpulan data dilakukan dengan cara :

1. Observasi
Data yang dikumpulkan dengan
menggunakan
observasi/pengamatan merupakan
kegiatan dengan menggunakan panca indera, bias penglihatan, penciuman, pendengaran, untuk memperoleh informasi yang diperlukan untuk menjawab masalah penelitian. Hasil observasi berupa aktifitas, kejadian, peristiwa, objek, kondisi atau suasana tertentu dan perasaan emosi. Observasi dilakukan untuk memperoleh gambaran nyata suatu peristiwa atau kejadian untuk menjawab pertanyaan penelitian.

2. Wawancara mendalam (in-depth interview) Wawancara mendalam dilakukan untuk mendapatkan informasi yang mendalam berkenaan dengan faktor determinan perilaku seksual pranikah di SMK Mega Rezki di Kota Makassar. Proses pengumpulan data ini akan menggunakan alat berupa pedoman wawancara (interview guide), tape recorder, dan alat tulis menulis.

3. Dokumentasi

Dalam penelitian ini dokumentasi yang digunakan adalah dokumen berbentuk gambar seperti foto, gambar hidup (video), dan lain-lain. Tujuannya untuk mendukung teknik pengumpulan data observasi, dan in-depth interview. 
Pengolahan Data

1. Mengumpulkan data dan informasi yang didapat melalui catatan lapangan dan rekaman pada saat indepth interview (wawancara mendalam) dilaksanakan.

2. Data yang telah diperoleh berupa hasil wawancara (data emik) selanjutnya dibuat dalam bentuk narasi (transkrip) dan diklasifikasikan menurut dimensi penelitian dan dibuat dalam bentuk matriks untuk memudahkan interpretasi data.

3. Matriks yang telah dibuat dirangkum, dicari tema dan polanya kemudian dinyatakan sebagai reduksi atau kesimpulan. Kesimpulan yang telah ada dikaji kembali menjadi konsep emik (konsep berdasarkan pernyataan informan) sesuai dengan dimensi penelitian.

4. Membandingkan konsep emik (konsep berdasarkan pernyataan informan) dengan konsep etik (teori) terkait dengan dimensi penelitian.

\section{Analisis Data}

1. Data Reduction

Data reduction atau reduksi data berarti merangkum, memilah hal-hal pokok, memfokuskan pada hal-hal yang penting, dicari tema dan polanya. Dengan demikian data yang telah direduksi akan memberikan gambaran yang jelas, dan mempermudah peneliti untuk melakukan pengumpulan data selanjutnya dan mencari bila diperlukan

2. Data Display (penyajian data)

Penyajian data dilakukan dalam bentuk uraian singkat, bagan hubungan antar kategori serta teks yang bersifat naratif dengan kata lain penyajian informasi yang tersusun. Conclusion Drawing/Verification (kesimpulan/verifikasi) Adalah tahapan melakukan penarikan kesimpulan dan verifikasi yang diharapkan dapat menjawab masalah yang sesuai dengan yang dirumuskan sejak awal sebagai tafsiran atau interpretasi terhadap data yang telah disajikan.

\section{Uji Keabsahan Data}

1. Triangulasi metode, yaitu menggunakan metode pengumpulan data yang berbeda beda untuk mendapatkan data dari sumber yang sama melalui wawancara mendalam (indepth interview). Observasi dan dokumentasi.

2. Triangulasi sumber, yaitu untuk mendapatkan data dari sumber yang berbeda dengan teknik yang sama. Sumber data berasal dari guru BK,
Psikologi dan siswa remaja di SMK Kota Makassar.

3. Triangulasi teori, yaitu menggunakan berbagai pemikiran dan pendapat para ahli serta hasil penelitian yang berhubungan dengan Faktor determinan perilaku seks pranikah di SMK Kota Makassar.

\section{HASIL PENELITIAN}

Dari hasil penelitian yang dilakukan dengan wawancara mendalam (Indeph-Interview) terhadap 7 informan mengenai Faktor Determinan Perilaku Seks Pranikah, diuraikan sebagai berikut:

1. Predisposing factors (Pengetahuan) Hasil kegiatan wawancara mendalam yang dilakukan pada Siswi terkait Perilaku Seks Pranikah, diperoleh hasil bahwa dari semua siswi hampir memiliki jawaban yang sama terkait pengetahuan Perilaku Seks Pranikah, adapun kutipan informan sebagai berikut:

“... yang saya tau itu kak kalau seks orang yang melakukan hubungan badan antara perempuan dan laki-laki, yang suka sama suka..."(I, 16 Tahun, 03 Agustus 2017)

“...oh...seks itu orang yang melakukan hubungan badan tapi belumpi menikah..." $(\mathrm{P}, 16$ tahun, 05 Agustus 2017)

Beberapa informan ada yang mengatakan bahwa hubungan seks itu dapat dilakukan pada pasangan suami istri, berikut kutipan informan tersebut :

“...menurutku toh kak seks itu bisa dilakukan kalau sudahpi menikah orang, kalau pacaran kan berpegangan tangan ji biasa juga sampai ciuman..."(R, 16 Tahun, 12 Agustus 2017)

“... Seks? Apa di' kak, itu kalau orang sudah menikah pasti melakukan seks atau hubungan suami istri, tapi menurutku kalau sekarang pacaran itu biasa juga melakukan seks..." (A, 17 Tahun, 21 Agustus 2017)

Seks bebas memang sudah menjadi hal yang biasa informan dengar mereka mengatakan bukan hanya suami istri yang dapat melakukan seks tetapi remaja juga itu biasa mereka lakukan karena banyak hal yang mereka lihat baik itu dari sosial media ataupun dari lingkungan, berikut kutipan ungkapan informan tersebut:

"... Hmm iye kak, seks itu toh yang kita biasa lakukan sama pacarta karena atas dasar suka sama suka, kalau tidak suka tidak mau tong jeki kak..." (L, 17 Tahun, 24 Agustus 2017) 
Hal yang sama dikemukakan oleh dua informan berikut ini:

“...menurutku, sekarang itu pacaran dak ada mi malunya kak, biasa ji itu kalau bermesraan didepan umum.." (S, 17 Tahun, 28 Agustus 2017)

“...kalau yang saya tau seks itu orang yang berhubungan intim dengan lawan jenis mau itu sudah menikah atau masih pacaran, kalau sudah suka sama suka bisa saja terjadi kak..."

(F, 17 Tahun, 30 Agustus 2017)

2. Enabling factors (Peran Sekolah, Paparan Media, Perilaku Pacaran)

a. Peran Sekolah

Dari hasil wawancara mendalam terkait perilaku seks pranikah, didapatkan hasil ungkapan informan yang berbeda-beda, berikut kutipan ungkapan informan tersebut:

“...pernahji kak saya dapat informasi mengenai seks bebas dari ibu guru, tapi begitu ji kak sekedar tau saja..."(I, 16 Tahun, 03 Agustus 2017)

“...kalau belajar mengenai dasar ilmu kesehatan dikelas kak biasa disinggung-singgung ji sedikit tentang seks bebas..."(P, 16 Tahun, 05 Agustus 2016)

“...pernahji kak saya dengar waktu seminar, tapi kudengar-dengarji saja, dak terlalu memperhatikan..."(R, 16 Tahun, 12 Agustus 2016)

Informasi yang baik sebenarnya dapat membantu dalam menentukan sikap dan perilaku terkait seks pranikah, dan dalam informan yang ditemukan ada sebagian yang pernah mendapatkan informasi terkait seks pranikah tetapi mereka mengatakan hanya sebatas tahu dan untuk menghindari perilaku itu belum tentu bisa dipastikan, berikut kutipan informan tersebut:

"...pernahji kak saya dengar waktu ada seminar di sekolah, tapi tidak saya ikuti sampai selesai karena keluarka dari ruangan.." (A, 17 Tahun, 21 Agustus 2017)

"...tidak tau mi deh kak, dak pernahka perhatikan, adakah atau tidak, tidak tau juga..."(L, 17 Tahun, 24 Agustus 2017)

“...pernahji kayaknya kak dari kesehatan yang ada, tapi tidak masukka ke ruangan..."(S, 17 Tahun, 28 Agustus 2017)

Hal yang sama dikemukakakn oleh informan lain, berikut kutipannya: "...iye ada ji kak itu hari guru bahas di kelas, kudengarji saja kak, begitu ji saja..."(F, 17 Tahun, 30 Agustus)

b. Paparan Media

Paparan media saat ini sangat luas terkait seks bebas, banyak media dan alat yang dapat digunakan untuk mendapatkan gambar atau video untuk menemukan gambar-gambar pornografi yang dapat dijadikan panutan, berikut kutipan informan tersebut:

“...biasa nonton film porno sama pacarku kak, jadi ikutan ki juga mau rasakan..."(I, 16 Tahun,03 Agustus 2017)

"...awalnya toh kak cerita-cerita ja, tapi kalau tidak adami dibikin biasa nontonki youtube setelah itu ciuman baru begitumi kak..." (P, 16 Tahun, 05 Agustus 2017)

"...lihat-lihat jeka kak biasanya di internet gaya pacarannya artis, mesra-mesra jadi kalau marahan ka sama pacarku kukasih lihat itu supaya mesra ka kembali..."(R, 16

Tahun, 12 Agustus 2017)

Beberapa informan mengatakan mereka suka menonton film remaja di televisi yang menceritakan tentang kisah percintaan sehingga dari situlah mereka ingin merasakan bagaimana rasa pacaran pada usia remaja, berikut kutipan informan tersebut:

“...perilaku pacaran juga dipengaruhi dari Tv dengan nonton sinetron dan ikut-ikutmi juga dengan gaya pacarannya..."(A, 17 Tahun, 21 Agustus 2017)

Berikut beberapa informan yang mangatakan bahwa mereka sering melihat atau menonton video porno di internet dan mereka tidak mendapatkan kesusahan dalam menemukan situsnya, berikut kutipan informan tersebut:

"...dari internet kak, karena banyak sekali disitu bisa kita lihat mengenai seks..."(L, 17 Tahun, 24 Agustus 2017)

“...lihat dari HandPhone ji kak, kalau buka ka bbm ku biasanya ada iklan mengenai seks, disitumi saya lihatlihat informasi mengenai seks.."(S, 17 Tahun, 28 Agustus 2017) “...awalnya nonton film ji kak, tapi lama kelamaan cari ka film lain yang agak romantic karena supaya baku sayang-sayang teruska sama pacarku..."(F, 17 Tahun, 30 Agustus 2017). 
c. Perilaku Pacaran

Perilaku pacaran untuk saat ini sangat sering kita temukan walaupun ditempattempat umum dan mereka tidak segan untuk memperlihatkan gaya pacaran yang mereka lakukan kepada orang lain, berikut kutipan informan tersebut:

"...biasaji kak, pergi malam minggu, biasa juga pegangan tangan, kadang ciuman, kalau tidak ada orang baku sandar-sandar, hehe..."(I, 16 Tahun, 03 Agustus 2017)

"...kemauan diri sendiri ji kak untuk pacaran ka', kan dewasa meki jadi mau meki cari teman jalan sama teman cerita..." (P, 16 Tahun, 05 Agustus 17)

"...seperti ji yang banyak orang lakukan kalau pacaran, cerita-cerita, pegangan tangan, kalau berdua ciuman, baru itu mi kak baku pegang-pegang, hehe..." $(\mathrm{R}, 16$ Tahun, 12 Agustus 2017)

Hal yang sama dikemukakan oleh beberapa informan lain, berikut kutipannya:

"...kalau kemana-mana selalu berdua, senagki pacaran karena ada yang kasihki perhatian lebih.."(A, 17 Tahun, 21 Agustus 2017)

"...enak kalau ada pacarta, karena dia antarki ke sekolah, pulangnya dia jemput lagi, kalau tidak adami jadwal sekolah lanjut meki pergi lending. Hehe.."(L, 17 Tahun, 24 Agustus 2017)

Beberapa informan mengatakan bahwa untuk melakukan seks mereka melihat situasi dan kondisi, bahkan mereka membawa pacar mereka kerumah sendiri untuk melakukan hubungan seks, berikut kutipan informan tersebut:

“...biasanya kalau berduaan ma kak baru sepi tempatnya berciuman ka atau kalau tidak ada orang di rumah saya bawa mi kerumah, di situ mi biasanya melakukan seks apalagi suka sama suka.."(S, 17 Tahun, 28 Agustus 2017)

“...kalau suka sama suka mi kak apalagi saya lama ma pacaran sama pacarku yang sekarang, biasa berhubungan badan ka sama dia.." $(F, 17$ Tahun, 30 Agustus 2017).

\section{Reinfocing factors (Teman Sebaya)}

Teman merupakan faktor yang paling berperan terhadap perubahan perilaku seseorang, banyak informan mengatakan bahwa perilaku yang mereka lakukan dikarenakan pengaruh dari teman sepergaulan mereka, berikut kutipan informan tersebut:

"...rata-rata temanku semua sudah pacaran, selalu pergi jalan, pokoknya kayak enak hidupnya karena ada teman ceritanya, jadi ikutanma juga..."(I, 16 Tahun, 03 Agustus 2017)

"...ada temannya temanku kak akrab sekali mi rasanya, jadi ujung-ujungnya temanku kasih makcomblangkan sama pacarku yang sekarang..."(P, 16 Tahun, 05 Agustus 2017)

“...dibilangi ki tidak gaul kalau tidak ada pacar ta kak, jadi na carikan ka teman ku juga pacar, tapi mau ja memang kalau ada pacarku..."(R, 16 Tahun,12 Agustus 2017)

Hal yang berbeda di kemukakan oleh informan lain, berikut kutipan ungkapnnya:

"...kalau temanku cerita masalah pacarnya, rasanya iri ki kak, jadi mau ki juga kalau ada pacarta supaya bisa masuk-masuk kalau cerita..."(A, 17 Tahun, 21 Agustus 2017)

Beberapa teman memang ada yang mendukung untuk berpacaran tetapi beberapa teman informan dibawah ini justru menyarankan agar informan putus dengan pacarnya karena mereka tidak ingin temannya merasakan sakit hati, berikiut kutipan informan tersebut:

"...sebenarnya ada juga temanku suruhka putus sama pacarku karena dia pernah sakit hati.."(L, 17 Tahun, 24 Agustus 2017)

"..Justru ada temanku yang sengaja suruh putus sama pacarku, tapi ternyata pas putus dia jalan mi sama pacarku..." (S, 17 Tahun , 28 Agustus 2017)

$\mathrm{Hal}$ yang berbeda diungkapkan oleh teman informan yang lain, bahwa pacaran itu tidak diperbolehkan oleh agama karena itu adalah salah satu perbuatan zina, berikut kutipan informan tersebut:

"...ada juga temanku larang pacaran karena pacaran dilarang sama agama..." $(F, 17$ Tahun, 30 Agustus 2017)

a. Informan Pendukung

Setelah dilakukan wawancara terhadap informan pendukung (Guru BK) pernyataan yang diungkapkan dari informan terkait seks pranikah sebagai berikut:

"...untuk anak-anak gaya pacaran yang sekarang, mereka sudah tidak malu lagi berbeda dengan dulu, memang disini ada siswa yang pacaran satu sekolah dan kemana-mana mereka selalu 
bersama, jika pada saat jam sekolah dia berduaan maka kami selaku guru bk memanggil agar menghadap ke ruangan bk setelah itu kami pun menyurati orang tuanya untuk datang ke sekolah agar memberikan pengawasan khusus pada anaknya. Adapun siswa yang bertengkar sama temannya hanya karena masalah cowok, mungkin mereka sama-sama suka tetapi cowok tersebut hanya memilih salah satunya itulah sebabnya mereka bertengkar. Dari siswa yang berpacaran negative tadi ada pula siswa yang berpacaran satu sekolah menjadikan motivasi agar dia rajin mengerjakan tugasnya dan tidak telat datang ke sekolah..."(Tn. S, 34 tahun).

b. Informan Kunci

Setelah dilakukan wawancara terhadap informan kunci (Psikolog) pernyataan yang diungkapkan dari informan terkait seks pranikah sebagai berikut:

“...untuk masa sekarang masalah seks pranikah pada remaja sangat tidak diherankan lagi, hal ini tidak sepenuhnya disebabkan oleh perubahan yang terjadi pada remaja itu sendiri tetapi ada faktor dari luar yang dapat menyebabkan remaja berbuat hal seperti itu pada saat pacaran. Untuk pacaran sendiri kita sudah tidak herankan lagi bahwa remaja sekarang sudah banyak yang pacaran bahkan sudah melewati batas dengan melakukan seks diluar nikah. Hal ini bisa juga diakibatkan karena rasa penasaran remaja terhadap sesuatu yang belum mereka rasakan, bisa juga diakibatkan pergaulan bebas, maraknya informasi pornoghrafi atau biasa disebabkan karena keluarga yang tidak harmonis sehingga memicu remaja untuk mencari ketenangan dan kebahagian mereka sendiri salah satunya dengan melakukan seks diluar nikah..."(N, Umur 48 Tahun)

\section{PEMBAHASAN}

1. Predisposing factors (Pengetahuan)

Pengetahuan (knowledge) adalah hasil penginderaan manusia, atau hasil tahu seseorang terhadap objek melalui indera yang dimilikinya (mata, hidung, telinga dan sebagainya) (Notoatmodjo, 2010). Pengetahuan tentang kesehatan reproduksi adalah mencakup apa yang diketahui oleh seseorang terhadap kesehatan reproduksi meliputi: sistem reproduksi, fungsi, prosesnya dan cara- cara pencegahan/penanggulangan terhadap kehamilan, aborsi, penyakitpenyakit kelamin (Notoatmodjo, 2007). beberapa anggapan yang salah tentang hubungan seksual diantaranya adalah kehamilan tidak mungkin terjadi bila hubungan seksual hanya dilakukan satu kali, hanya dilakukan di usia muda, sebelum dan sesudah menstruasi, antara masa menstruasi; dilakukan dengan teknis coitus interuptus, atau sesudahnya segera minum soft drinks tertentu. Oleh karena itu mereka merasa tidak merasa perlu memakai kontrasepsi.

Dari hasil informan yang didapatkan masih banyak ditemukan informan yang masih kurang pemahaman tentang pengetahuan seksual pranikah, Seks bebas memang sudah menjadi hal yang biasa informan dengar mereka mengatakan bukan hanya suami istri yang dapat melakukan seks tetapi remaja juga biasa melakukan seks bebas.

2. Enabling factors (Peran Sekolah, Paparan Media, Perilaku Pacaran)

Sekolah merupakan tempat dimana anak melakukan kegiatan belajar secara terarah dan terprogram dengan baik. Pergaulan sekolah berarti segala kegiatan antara guru dengan siswa yang meliputi: kegiatan pembelajaran, interaksi sosial, serta komunikasi sosial antara warga sekolah. Sehingga dapat disimpulkan bahwa pergaulan sekolah adalah lingkungan dimana guru dan siswa melakukan aktifitas belajar mengajar serta interaksi sosial dan komunikasi personal antar warga sekolah (Hadi, 2011).

Menurut informan dalam penelitian yang telah dilakukan informan pernah mendapatkan informasi dari seminarseminar yang diadakan di sekolah dan pada saat guru mengajar di kelas, tetapi kebanyakan siswa kurang memperhatikan pada saat pemaparan materi tentang kesehatan reproduksi wanita dan pengaruh seks bebas.

Media massa bisa dikatakan sebagai media pembelajaran untuk memperoleh informasi dan menambah wawasan pengetahuan karena mengandung pesan sederhana sampai pesan yang sangat kompleks. Media massa cetak dan elektronik dianggap sebagai sumber informasi seksual yang lebih penting dibandingkan oran tua dan teman sebaya. Media massa memberikan gambaran yang lebih baik mengenai keinginan, mengenai cinta, dan kebutuhan seksualitas secara luas, walaupun terkadang informasi yang 
didapat mengenai hal tersebut kurangrelevan dan digambarkan dengan sangat vulgar (Sarwono, 2013).

Berdasarkan hasil observasi dalam penelitian ini yang terlihat seiring dengan pesatnya arus perkembangan ilmu pengetahuan dan teknologi. Tentu saja ini membawa pengaruh buruk bagi perkembangan remaja yang sedang bergejolak seperti yang terjadi di smk Kota Makassar, hal ini termasuk informasi tentang seksual tanpa batas. Tidak sedikit informasi yang diperoleh remaja disalah artikan sehingga menimbulkan berbagai perilaku menyimpang.

Dengan semakin mudahnya akses informasi, khususnya internet yang dapat menyediakan stimulus atau rangsangan terhadap hal-hal yang berkaitan dengan hasrat seksual, maka hasrat seksual yang telah ada semakin „diasah" oleh pornografi yang dapat dengan mudah ditemui di internet. begitupun dengan pengaruh yang disebabkan oleh media seperti Tv, internet untuk mengakses video porno.

Perilaku seks pranikah adalah kegiatan yang dilakukan secara berdua pada waktu dan tempat yang telah disepakati bersama dari dua orang lain jenis yang belum terikat pernikahan. Seks pranikah merupakan aktivitas seksual yang dilakukan tanpa mengindahkan nilai-nilai dan norma-norma dalam masyrakat yang mengaturnya.

Berdasarkan hasil observasi dan penelitian, remaja dalam penelitian ini mempunyai pemahaman yang keliru tentang cinta, tidak jarang remaja terlibat dalam pergaulan yang terlalu bebas dan permisif, apapun boleh dilakukan asal dilakukan atas dasar suka sama suka, tidak ada lagi pertimbangan berdasarkan hati nurani dan akal sehat, dengan dalih cinta apapun akan dilakukan, biasanya remaja akan sadar ketika efek atau akibat dari pergaulan bebas tersebut membawa dampak yang negative, Kebanyakan remaja melakukan hal tersebut hanya untuk kesenangan semata. didapatkan pula bahwa yang menyebabkan perilaku seksual remaja pranikah adalah sebagian besar mengatakan karena kemauan diri sendiri yang mulai tertarik terhadap lawan jenisnya, adanya keinginan pacaran tidak bisa disembunyikan lagi oleh remaja dan mengatakan bahwa perasaanya murni timbul sendiri dalam hati tanpa ada paksaan dari siapapun dan diusia remaja dalam fase labilitasnya sangat tidak mungkin jika harus membiarkan perasaannya dan tidak meluapkannya sehingga remaja lebih cenderung mengikuti perasaannya itu berarti bahwa adanya dorongan biologis terhadap remaja sangat berpengaruh terhadap perilaku pacaran yang beresiko, hal tersebut dikarenakan remaja tidak mampu lagi membendung perasaannya.

3. Reinfocing factors (Teman Sebaya)

Teman sebaya merupakan dunia nyata kawula muda yang mengharapkan panggung dimana dia dapat menguji diri sendiri dan orang lain. Pada usia remaja lebih banyak berada diluar bersama dengan teman-teman sebaya sebagai kelompok, maka dapatlah dimengerti bahwa pengaruh teman-teman sebaya pada sikap, pembicaraan, minat, penampilan dan perilaku lebih besar pengaruhnya dibandingkan keluarga (Hurlock, 2012).

Berdasarkan hasil observasi yang didapatkan bahwa salah satu penyebab perilaku seksual pranikah pada remaja di SMK Kota Makassar adalah pengaruh teman sebaya, karena seringnya mengikuti ajakan teman yang berperilaku seksual sehingga remaja cenderung meniru gaya pacaran teman sebayanya, misalnya pulang sekolah siswa remaja tidak langsung pulang kerumahnya melainkan keluyuran ke tempat-tempat yang biasa remaja datangi, hal itulah yang memicu remaja untuk pacaran yang mengarah ke perilaku seksual.

Berdasarkan hasil observasi dalam penelitian ini yang terlihat bahwa remaja dalam penelitian ini sangat mudah terpengaruh dengan teman sebayanya apalagi ketika berada diluar sekolah, terkadang remaja memanfaatkan kesempatan tersebut untuk bergaul dengan teman-temannya dengan mengunjungi tempat-tempat yang nyaman dan bebas sehingga remaja bebas melakukan apa saja tanpa memikirkan dampaknya sehingga pengaruh pergaulan bebas tidak dapat dihindari lagi. Akibat pergaulan bebas yang dilakukan pasangan remaja akan mempengaruhi terjadinya perilaku seksual pranikah.

Berdasarkan hasil penelitian yang dilakukan di SMK Kota Makassar tersebut didapatkan adanya kesesuaian dengan hasil indepth interview (wawancara mendalam) dengan observasi (pengamatan) terhadap siswa dan siswi, peneliti mendapatkan data yang bervariasi mengenai faktor determinan perilaku seks pranikah dan tentu saja sebagian remaja 
mengabaikannya meskipun mereka tahu akan dampak yang ditimbulkan oleh perilaku seks pranikah. Hal ini terlihat dengan banyaknya kasus yang diakibatkan oleh perilaku seks pranikah pada siswa saat peneliti mengumpulkan data.

\section{KESIMPULAN}

Setelah dilakukan analisa secara mendalam terhadap perilaku seksual pranikah pada siswa SMK Mega Rezky di Makassar diperoleh kesimpulan sebagai berikut:

1. Timbulnya keinginan remaja melakukan seksual pranikah disebabkan oleh adanya rangsangan seksual, adapun rangsangan seksual itu sendiri berasal dari:

a. Menonton video, gambar porno, ataupun adegan lain yang berbau seks.

b. Seringnya berduaan sama pasangan sehingga mengarah ke rangsangan secara seksual.

c. Membayangkan adegan seks, dimana imajinasi yang muncul merupakan hasil akumulasi dari pengalaman remaja tersebut selama berinteraksi dengan lingkungan sekitar. d. Rangsangan seksual yang tidak disadari dilakukan oleh remaja itu sendiri misalnya karena dari rasa cobacoba melakukan seksual, sehingga merasa ketagihan.

\section{SARAN}

1. Bagi pihak SMK Kota Makassar

Diharapkan agar pihak sekolah memberikan sosialisasi secara intensif untuk melakukan penyuluhan yang berkaitan dengan seksual pranikah, seperti dampak negative dari seksual pranikah dan lebih meningkatkan pengawasan diruang lingkup sekolah mengenai perilaku pacaran siswa/ siswi.

2. Bagi peneliti selanjutnya

Perlu dilakukan penelitian lebih lanjut tentang perilaku seksual pranikah dengan metode kualitatif dengan pendekatan atau variabel-variabel yang berbeda untuk melihat perkembangan dari hasil peneliti sebelumnya.

\section{DAFTAR PUSTAKA}

Ahmad Taufik, 2013. Persepsi Remaja Terhadap Perilaku Seks Pranikah (Studi Kasus SMK Negeri 5 Samarinda), ejournal sosiastri-sosiologi.

Ali, M. 2010. Psikologi Remaja. Jakarta: Bumi Aksara.

Bandura, A. 1990. Perceived Self Efficacy in The Exercise of Control Over AIDS Infection.

BKKBN 2015, Remaja Pelaku Seks Bebas Meningkat. Bkkbn.go.id.

Chaerani, Ika. 2010. Pengaruh faktor Personal dan Lingkungan tehadap Perilaku Seksual Pranikah pada Remaja di SMA Negeri 1 Baturraden dan SMA Negeri 1 Purwokerto. Universitas Diponegoro. Semarang.

Dewi, A. P. 2012. Hubungan Karakteristik Remaja, Peran Teman Sebaya, dan Paparan Pornografi dengan Perilaku Seksual Remaja di Kelrahan Pasir Gunung Selatan Depok, Universitas Indonesia.

Dianawati, A., 2003. Pendidikan Seks Untuk Remaja, Jakarta: Kawan Pustaka

Dinkes Sulsel.2012 . Profil Kesehatan Provinsi Sulawesi Selatan tahun 2012.

Feriyani, B., \& Fitri, A. R. 2010. Perilaku seksual pranikah ditinjau dari intensitas cinta dan sikap terhadap pornografi pada dewasa awal. Jurnal Psikologi.

Green, L. W. \& Kreuter, M. W. 2000. Health Promotion Planning London, Mayfield Publishing Company.

Hakim, L. E. 2014. Fenomena Pacaran Dunia Remaja. Riau; Zanafa Publishing.

Haryanto, R 7 Ketut, S. 2013. Perilaku seksual pranikah pada Siswa SMA Negeri 1 Palu. JurnalAcademica. Universitas Tadulako.

Hurlock, E. B. 1993. Psikologi Perkembangan: SuatuPendekatan Sepanjang Rentang Kehidupan. Jakarta: Erlangga.

Juleha, E. 2007. Beberapa Faktor yang Berhubungan Dengan Perilaku Seksual Remaja(Studi pada Kelas III SMU Negeri 9 Cirebon).

Kemenkes 2013. Profil Pengendalian Penyakit dan Penyehatan Lingkungan. Jakarta: Kementrian Kesehatan 